\title{
IAMJ
}

INTERNATIONAL

AYURVEDIC

MEDICAL JOURNAL

Review Article

ISSN: 2320-5091

Impact Factor: 6.719

\section{A REVIEW OF RAKTAVAHA SROTAS AND ITS DISEASES}

\section{$\underline{\text { Ravindra Singh Baghel }}^{1}$, $\underline{\text { Rita Marwaha }}^{2}$, Swatantra Kumar Chourasia $^{3}$, Shiba Datta Panda $^{4}$}

${ }^{1}$ PG Scholar, ${ }^{2}$ Professor, H.O.D \& Guide, ${ }^{3}$ Assistant Professor, ${ }^{4}$ Assistant Professor

P.G. Dept. of Rachna Sharir, Pt. Khushilal Sharma Govt. (Autonomous) Ayurveda College \& Institute, Bhopal, (M.P.). India

Corresponding Author:ravi.baghel3883@gmail.com

\section{https://doi.org/10.46607/iamj1909082021}

(Published Online: August 2021)

Open Access

(C) International Ayurvedic Medical Journal, India 2021

Article Received: 02/07//2021 - Peer Reviewed:11/07/2021 - Accepted for Publication:15/07/2021

Check for updates

\section{ABSTRACT}

The subject which deals with the study of the human body and its part is called "Rachna Sharir" which forms the basic principle for understanding the concept of Ayurveda. In Ayurveda, the principle of Srotas is like the roots of the tree. The channel that transport nutrition to their destiny is called Srotas. The human body is the collaboration of the Srotas. Srotas take part in the modification, conveyance, absorption and excretion of many substances which are transported through them. The number of Srotas are different by different authorities of Ayurveda. The Srotas have their self Mulasthan or root. Any disturbance in the Srota, at the structural or functional level, leads to the commencement of diseases. Every Srotas have different functions and Dusti Lakshana. Raktavaha Srotas is the Srotas which is related to blood circulation and its formation. Its Mulasthana are Yakrit, Pleeha and Raktavahinidhamani as mentioned the Ayurvedic literatures. There are many diseases of Raktavaha Srotas, which occurs as a result of Srotas Dusti. The disease of the Raktavahasrotas is Kustha, Visrpa, Pidika, Kamala, Asrgdar, Arubuda, Arsha etc. all the skin diseases, haemolytic disease, gynaecological disorders, metabolic disorders. The diseases of Raktavahasrotas are important for diagnosis and clinical practices. The presentation is aimed to review the concept of Raktavaha Srotas and its importance.

Keywords: Srotas, Mulastha, RaktavahaSrotas 


\section{INTRODUCTION}

Ayurveda is the science of life and longevity. Sharir is a basic stream of Ayurveda classics which deals with structural and functional aspects of the body. Ayurveda has very vividly described the anatomy of the human body. These basic constituents are continuously circulating through different channels or carriers in our bodies. These transportation systems of the body are well known as Srotas. Ayurvedic classics signify 'Srotamayam hi Shariram' means comprising of paths or channels. Srotasas are innumerable in numbers and represent the inner transport system of the body. Generally, the word Srotas is used as a common term pointing to all the macro and micro pathways operating in the living organism. The word Srotas means channels or passages in which some tissue is formed, some material is metabolized, secreted or transported. The term Srotas is derived from Sanskrit root 'Sru'Gatau which represents i.e., excretion, filtration, oozing, secretion, transportation etc. The synonyms of Srotas are Sira (vein), Dhamni (arteries), Rasayani (lymphatics), Rasvahini (capillaries), Nadi (ducts), Pantha (passage), Marga (channels), Sharirchidrani (sphincters), Sthanani (site), Niketa (places), Ashaya (recipient), Rasvahaniya (lymphatic), Samvrita-asamvrita (open and blind passages), Ashayas (spaces), Sharir Dhatwaavaksh Lakshyana-alakshyana (visible and invisible interstitial) ${ }^{1}$. Srotas are the inner transport system of the body which provides a platform for activities of another important bio factor like three Doshas, seven Dhatus etc ${ }^{2}$.

Srotas are the minutes the structural and functional unit of each organ, which play a very crucial role in biological processes such as physiological and pathological processes of human body.

\section{Structure of Srotas}

Colour-Srotas have a colour similar to that of their Dhatu

Size- Anu (superfine), Sthula (visible to naked eyes)

Shape- Vritta (barrels shaped), Dirgha (protracted), Pratana (marked like a net) ${ }^{3}$

Types of Sortas- -Different authorities of Ayurveda claims different type of Srotas. They classified Srotas on the different logics such as anatomical, physiological, pathological, surgical etc. According to Acharya Charak, types of Srotas mentioned as 13 in number, they are Pranavaha, Udakavaha, Annavaha, Rasavaha, Rudhiravaha, Mamsavaha, Medasvaha, Asthivaha, Majjavaha, Sukravaha, Mutravaha, Purisavaha and Swedavaha ${ }^{4}$. Acharya Sushrut has classified the Sortas into two major groups, they are Bahirmukha Srotas and Antramukha Srotas. Sushrut said that Srotamsi which are enumerated as nine in numbers are Bahirmukha i.e., major external openings of the body. These are two ears, two eyes, one mouth, two nostrils, one anal opening and one urethral opening (nine) in males while in females there are three more openings, two breasts (nipples) and one vaginal opening ${ }^{5}$. According to Acharya Sushrut, types of Srotas is mentioned as 11 pairs, they are Pranavaha, Udakavaha, Rasavaha, Raktavaha, Mamsavaha, Medavaha, Mutravaha, Purishavaha, Sukravaha and Artvavaha Srotas ${ }^{6}$. These are Antramukha Srotas. Ashtang Hridaya also present his views identical to Sushrut and he states that there are nine opening or Bahyasrotas in man while the females have $12^{7}$.

Causes of Sroto Dusti: According to Acharya Charak food and behaviour which are similar to Doshas and dissimilar to Dhatus in properties causes morbidity in Srotas $^{8}$. Sushrut Samhita did not mention any causes of Srotas, he said, an injury to the Srotas revealed incurable conditions that's why such information should be given to the patient and his attended and proceed the treatment to remove the foreign body ${ }^{9}$.

\section{Srotas Dusti Laskhana}

Acharya Charak has mentioned 4 types of Srotas Dushti Lakshana. Atipravati (Enhanced flow), Sanga (obstruction), Siragranthi (formation of nodules) and Vimargagamana (flow of contents in the wrong direction) are the symptoms of Srotas Dushti ${ }^{10}$. Astangahridaya, and Astangasamgraha, have a tantamount view on Srotadushti. Acharya Sushrut has not mention Srotadushti Lakshana but states Viddha Lakshana and its specific consequences. 


\section{Mulasthan of Raktavahasrotas}

Yakrit and Pleeha (ch.vi 5/7-8), Raktavahadhamani, Yakrit and Pleeha (su.sa 9/12), Yakrit and Pleeha (As sam.6/14)

To know the anatomy of Raktavaha Srotas their $\mathrm{Mu}$ lasthan is considered. Both Acharya Charak and Acharya Vaghbhat has considered Yakrit and Pleeha, but Sushrut has described Yakrit Pleeha and Raktavahinidhamanis as Mulas. Raktavahanidhamanis are none other than all blood vessels. Acharya Sushrut being a great surgeon always think about such structures from a clinical-surgical point of view and was more practical. In Ayurveda, there is no clear details of Yakrit (liver) and Pleeha (spleen).

Liver- The liver is the heaviest gland of the body, weighing about $1.4 \mathrm{~kg}$ (about $3 \mathrm{lb}$ ) in an average adult. Of all of the organs of the body, it is second only to the skin in size. The liver is inferior to the diaphragm and occupies most of the right hypochondriac and part of the epigastric regions of the abdominopelvic cavity ${ }^{11}$. Hepatocytes from complex three-dimensional arrangements called hepatic laminae. The hepatic laminae are plates of hepatocytes one cell thick bordered on either side by the endothelial-lined vascular spaces called hepatic sinusoids. The hepatic laminae are highly branched irregular structures. Grooves in the cell membranes between neighbouring hepatocytes provide spaces for canaliculi (described next) into which the hepatocytes secrete bile. Bile, a yellow, brownish, or olive-green liquid secreted by hepatocytes, serves as both an excretory product and a digestive secretion. Bile canaliculi are small ducts between hepatocytes that collect bile produced by the hepatocytes. From bile canaliculi, bile passes into bile ductules and then bile ducts. The bile ducts merge and eventually form the larger right and left hepatic ducts, which unite and exit the liver as the common hepatic duct. The common hepatic duct joins the cystic duct from the gallbladder to form the common bile duct. From here, bile enters the duodenum of the small intestine to participate indigestion ${ }^{12}$

\section{Blood supply of liver}

The liver receives blood from two sources. From the hepatic artery, it obtains oxygenated blood, and from the hepatic portal vein, it receives deoxygenated blood containing newly absorbed nutrients, drugs, and possibly microbes and toxins from the gastrointestinal tract. Branches of both the hepatic artery and the hepatic portal vein carry blood into hepatic sinusoids, where oxygen, most of the nutrients, and certain toxic substances are taken up by the hepatocytes. Products manufactured by the hepatocytes and nutrients needed by other cells are secreted back into the blood, which then drains into the central vein and eventually passes into a hepatic vein ${ }^{13}$.

\section{Function of liver}

1. Carbohydrate metabolism- The liver is especially important in maintaining a normal blood glucose level. When blood glucose is low, the liver can break down glycogen to glucose and release the glucose into the bloodstream. The liver can also convert certain amino acids and lactic acid to glucose, and it can convert other sugars, such as fructose and galactose, into glucose. When blood glucose is high, as occurs just after eating a meal, the liver converts glucose to glycogen and triglycerides for storage.

2. Lipid metabolism- Hepatocytes store some triglycerides; break down fatty acids to generate ATP; synthesize lipoproteins, which transport fatty acids, triglycerides, and cholesterol to and from body cells; synthesize cholesterol and use cholesterol to make bile salts.

3. Protein metabolism- Hepatocytes deaminate (remove the amino group, $\mathrm{NH} 2$, from) amino acids so that the amino acids can be used for ATP production or converted to carbohydrates or fats. The resulting toxic ammonia (NH3) is then converted into the much less toxic urea, which is excreted in the urine. Hepatocytes also synthesize most plasma proteins, such as alpha and beta globulins, albumin, prothrombin, and fibrinogen.

4. Processing of drugs and hormones- The liver can detoxify substances such as alcohol and excrete drugs such as penicillin, erythromycin, and sulfonamides into bile. It can also chemically alter or excrete thyroid hormones and steroid hormones such as oestrogens and aldosterone. 
5. Excretion of bilirubin- As previously noted, bilirubin, derived from the heme of aged red blood cells, is absorbed by the liver from the blood and secreted into bile. Most of the bilirubin in bile is metabolized in the small intestine by bacteria and eliminated in faeces. Synthesis of bile salts. Bile salts are used in the small intestine for the emulsification and absorption of lipids.

6. Storage- In addition to glycogen, the liver is a prime storage site for certain vitamins (A, B12, D, $\mathrm{E}$, and $\mathrm{K}$ ) and minerals (iron and copper), which are released from the liver when needed else wherein the body.

7. Phagocytosis- The stellate reticuloendothelial (Kupffer) cells of the liver phagocytize aged red blood cells, white blood cells, and some bacteria.

8. Activation of vitamin D- The skin, liver, and kidneys participate in synthesizing the active form of vitamin $\mathrm{D}^{14}$.

Spleen-The oval spleen is the largest single mass of lymphatic tissue in the body. It is a soft, encapsulated organ of variable size, but on average it fits in a person's open hand and measures about $12 \mathrm{~cm}$ (5 in.) in length. A capsule of dense connective tissue surrounds the spleen and is covered in turn by a serous membrane, the visceral peritoneum. Trabeculae extend inward from the capsule. The capsule plus trabeculae, reticular fibres, and fibroblasts constitutes the stroma of the spleen; the parenchyma of the spleen consists of two different kinds of tissue called white pulp and red pulp. White pulp is lymphatic tissue, consisting mostly of lymphocytes and macrophages arranged around branches of the splenic artery called central arteries. The red pulp consists of blood-filled venous sinuses and cords of splenic tissue called splenic cords of Billroth's cords. Splenic cords consist of red blood cells, macrophages, lymphocytes, plasma cells, and granulocytes. Veins are closely associated with the red pulp. Blood flowing into the spleen through the splenic artery enters the central arteries of the white pulp. Within the white pulp, B cells and T cells carry out immune functions, similar to lymph nodes, while spleen macrophages destroy blood-borne pathogens by phagocytosis. Within the red pulp, the spleen performs three functions related to blood cells:

1. Removal by macrophages of ruptured, worn out, or defective blood cells and platelets.

2. Storage of platelets, up to one-third of the body's supply.

3. Production of blood cells (hemopoiesis) during fetal life $\mathrm{e}^{15}$.

Raktavahasrotas Dushti Hetu-Acharya Charak has mentioned various factors of Raktavahasrotasdusti. They are due to intake of Vidahianna (food which causes burning sensation) and Pana (drinks), Snigdha (oily), Ushna (hot) Drava (liquid) food consummation along with exposure to Atapa (sunlight) and Anila (air) which lead to Raktavahasrotas Dushti ${ }^{16}$.

Raktavahasrotas Vyadhi- Different classics of Ayurveda has mentioned various types of disease which are due to the result of Raktavahasrotas Dushti. Table no.1 shows the difference of Raktavahasrotas Vyadhi mentioned in ancient works of literature.

Table 1: Raktavahasrotas Vyadhiin different classics

\begin{tabular}{|l|l|l|}
\hline Charak $_{\text {Samhita }}{ }^{17}$ & Sushrut Samhita $^{18}$ & Ashtanga Hridya $^{19}$ \\
\hline Kustha (all types of skin disease) & + & + \\
\hline Visarpa(erysipelas) & + & + \\
\hline Pidika (pimples) & + & + \\
\hline Raktapitta (haemolytic disorder) & + & + \\
\hline Gulma (abdominal tumour) & + & + \\
\hline Kamala (jaundice) & + & + \\
\hline Pleeharoga (Splenomegaly) & + & - \\
\hline Vianga (dark shade) & + & + \\
\hline Vidradhi (abscess) & + & + \\
\hline
\end{tabular}




\begin{tabular}{|c|c|c|}
\hline Nilika (bluishness) & - & - \\
\hline Tilakalka (Birth marks like sesamum) & - & - \\
\hline $\begin{array}{l}\text { Asrigdar (all types of menstrual disorder like } \\
\text { menorrhagia) }\end{array}$ & - & + \\
\hline Pipalava (Port wine mark) & - & - \\
\hline Dadaru (Ringworm) & - & - \\
\hline Charmadal (Dermatitis) & - & - \\
\hline Switra (Leucoderma) & - & - \\
\hline Pama (Papules) & - & - \\
\hline Koth (Urticaria) & - & - \\
\hline Rakta mandala (Red circular patches) & - & - \\
\hline- & Masak (moles) & - \\
\hline $\begin{array}{l}\text { Gudapaka (inflammation of anus) and } \\
\text { Medhrapaka (inflammation of penis) }\end{array}$ & + & - \\
\hline- & Mukhapaka (mouth ulcer) & - \\
\hline- & Lingapaka & - \\
\hline- & Vatarakta (gout arthritis) & + \\
\hline- & Indralupta (alopecia) & - \\
\hline- & Arsha (haemorrhoids) & - \\
\hline- & Arbuda (tumour) & - \\
\hline- & Angamarda (whole-body pain) & - \\
\hline- & - & - \\
\hline- & - & Agninash (lost of digestive power) \\
\hline- & - & Tama pravesh (blackout) \\
\hline- & - & Lalima in Sarir (body) and Netra \\
\hline
\end{tabular}

\section{Management of Raktavaha Srotas}

Acharya Charak has stated that the diseases caused by blood, one should adopt the treatment which evacuates blood and Pitta such as Virechana (Purgation), Upvasa (fasting) and Raktamokshana (bloodletting) ${ }^{20}$. Virechana- The process of expelling unwanted or wastage material through the downward track is called Virechana (purgation). The drugs used in Virechana are Ushna (hot), Tikshna (sharp), Sukshma (subtle), Vyavayi (those pervading the entire body before getting digested) and Vikashi (those causing looseness of joints). Langhana (fasting) Whatever is capable to reduce the body is known as 'Langhana' or reducing therapy. There are many types of Langhana mentioned in Ayurveda texts. Raktamokshana The process of letting out impure Dosha from the blood with the help of surgical instruments or non-surgical instruments is called Raktamokshana. For example- Jalukavacharana, Shringavacharana, Alabuavacharana and Ghatiyantra.

\section{CONCLUSION}

According to the construction of the Srotas, the Srotas are the empty passage, provenance from the root collocation, loft within the whole body to acts as a carriage system for the supply of nutritional needs of the organism. Raktavaha Srotas from its origin, we can compare with the Haemopoietic system. From its root of origin, we come to know liver and spleen act as a compilation of blood and from the circulation passage we can also juxtapose with the circulatory system of the body and also the damaged red blood cells are isolated from circulation and devasted by fixed phagocytic macrophages in the spleen and liver, and the remainder products are recycled. The liver and spleen perform a major role life cycle of RBC, its destruction and recycling of components. The anatomical change in liver such as Congenital Billiary Atresia, Billiary cyst etc. Congenital Billiary Atresia is a life-threatening condition in which the bile duct is impeded. This obstructs the flow of bile from liver. Biliary cyst is a 
condition in which bile duct have abnormal dilatation, which obstruct the flow of bile and hampers the liver functions. There are wide range of anomalies of spleen including shape, location, notches, clefts, spleenopancreatic fusion, wandering spleen and many more. These anomalies affect directly or indirectly the function of spleen. Considering the above aspect Yakrut (Liver) and Pleeha (Spleen) are considered as roots of Raktavaha Srotas.

\section{REFERENCES}

1. Shastri kashinath, vidyotini commentary on charak Samhita, Varanasi, chaukhambha, Bharti Academy, 2018, Ch. Viman 5/09, Page- 712

2. Shastri kashinath, vidyotini commentary on Charaka Samhita, Varanasi, chaukhambha, Bharti Academy, 2018, Ch. Viman 5/06, Page- 710

3. Shastri kashinath, vidyotini commentary on charak Samhita, Varanasi, chaukhambha, Bharti Academy, 2018, Ch. Viman 5/25, Page- 714

4. Shastri kashinath, vidyotini commentary on charak Samhita, Varanasi, chaukhambha, Bharti Academy, 2018, Ch. Viman 5/06, Page- 710

5. Shastri Dr. Ambika Dutta, Sushrut Samhita, Ayurveda Tattva Sandipika, Varanasi, Chaukhambha Sanskrit Sanstha, Varanasi 2012, Su. Sharir 5/10, Page No.- 56

6. Shastri Dr. Ambika Dutta, Sushrut Samhita, Ayurveda Tattva Sandipika, Varanasi, Chaukhambha Sanskrit Sanstha, Varanasi 2012, Su. Sharir 9/12, Page No.- 96

7. Kaviraj Gupta Atrideva, AstangaHrdayamVidyotini tika Varanasi: ChaukhambhaPrakashan Varanasi, Asthanghridayasharir 3/40-41Page no.254

8. Shastri kashinath, vidyotini commentary on charak Samhita, Varanasi, chaukhambha, Bharti Academy, 2018, Ch. Viman 5/23, Page- 714

9. Shastri Dr. Ambika Dutta, Sushrut Samhita, Ayurveda Tattva Sandipika, Varanasi, Chaukhambha Sanskrit Sanstha, Varanasi 2012, Su. Sharir 9/12, page no.- 97

10. Shastri kashinath, vidyotini commentary on charak Samhita, Varanasi, chaukhambha, Bharti Academy, 2018, Ch. Viman 5/24, Page- 714

11. Gerard J. Tortora, Bryan Derrickson, Principles Of Anatomy \& Physiology, $15^{\text {th }}$ Edition, Wiley 2017-Page No.- 922

12. Gerard J. Tortora, Bryan Derrickson, Principles Of Anatomy \& Physiology, $15^{\text {th }}$ Edition, Wiley 2017-Page No.- 922 \& 924

13. Gerard J. Tortora, Bryan Derrickson, Principles Of Anatomy \& Physiology, $15^{\text {th }}$ Edition, Wiley 2017-Page No.- 925

14. Gerard J. Tortora, Bryan Derrickson, Principles Of Anatomy \& Physiology, $15^{\text {th }}$ Edition, Wiley 2017-Page No.- 926
15. Gerard J. Tortora, Bryan Derrickson, Principles Of Anatomy \& Physiology, $15^{\text {th }}$ Edition, Wiley 2017-Page No.- 819

16. Shastri kashinath, vidyotini commentary on Charaka Samhita, Varanasi, chaukhambha, Bharti Academy, 2018, Ch. Viman 5/14, Page- 713

17. Shastri kashinath, vidyotini commentary on charak Samhita, Varanasi, chaukhambha, Bharti Academy, 2018, Ch. Sutra 28/11-12, Page- $571 \& 572$

18. Shastri Dr. Ambika Dutta, Sushrut Samhita, Ayurveda Tattva Sandipika, Varanasi, Chaukhambha Sanskrit Sanstha, Varanasi 2012, Su. Sutra 24/11, Page No.- 132

19. Dr Brahamanand Tripathi, AshtangHridaya, Varanasi, Chaukhambha Sanskrit Sanstha, Varanasi 2015, Asthanghridaya Sutra 11/09 Page no. 161

20. Shastri kashinath, vidyotini commentary on charak Samhita, Varanasi, chaukhambha, Bharti Academy, 2018, Ch. Sutra 24/18, Page- 445

\section{Source of Support: Nil \\ Conflict of Interest: None Declared}

How to cite this URL: Ravindra Singh Baghel et al: A Review Of Raktavaha Srotas And Its Diseases. International Ayurvedic Medical Journal \{online\} 2021 \{cited August 2021\} Available from:

http://www.iamj.in/posts/images/upload/1722_1727.pdf 